\title{
Australian Journal of \\ Growth and biomass of sunflower under different nitrogen levels and available water in the soil of a semi-arid region
}

\section{Samuel Silva ${ }^{1}$, José Alberto Ferreira Cardoso ${ }^{2}$, Hallyson Oliveira $^{2}$, Ronaldo do Nascimento ${ }^{2}$, Rafaela Félix Basílio Guimarães ${ }^{2}$, Armindo Bezerra Leão ${ }^{2}$}

\author{
${ }^{1}$ Federal Institute of Alagoas (IFAL) Campus Piranhas, Alagoas, Brazil \\ ${ }^{2}$ Federal University of Campina Grande, Academic Unit of Agricultural Engineering, Campina Grande, 58.109. \\ 970, Paraíba, Brazil
}

\section{*Corresponding author: hallysonoliveira_@hotmail.com}

\begin{abstract}
The adequate water supply and nitrogen in the soil is essential for the growth and development of plants. Sunflower is the target of several studies of such factors due to the economic importance and the needs to expand in the semi-arid regions of Brazil. This work aimed to evaluate the growth variables, measured at 80 days after sowing (DAS), and the biomass obtained at 100 DAS of the Helio 253 sunflower hybrid under the effect of nitrogen and water levels. The experiment was conducted in a greenhouse in the city of Campina Grande- PB, in split-plot of a completely randomized design with four moisture levels in the soil $(50,75,100$ and $125 \%$ of available water) and four nitrogen rates $\left(30,60,90\right.$ and $\left.120 \mathrm{~kg} \mathrm{ha}^{-1}\right)$. Among all levels of available water in the soil, the stem diameter (SD) ranged from 13.6 to $19.6 \mathrm{~mm}$ and the plant height (PH) from 93 to $107 \mathrm{~cm}$. Plants with 100\% AW showed a leaf area (LA) $45 \%$ greater than the treatment with higher water stress. The heads had an average diameter between 83 and $98 \mathrm{~mm}$, the dry biomass of the heads (DBC) and total dry biomass (TDB) ranged from 45 to $55 \mathrm{~g}$ and of 65 to $101 \mathrm{~g}$, respectively. The weight of a thousand seeds per head (W1000) obtained minimum and maximum of 49 and $66 \mathrm{~g}$. The stem diameter ranged between 14.4 to 18.3 $\mathrm{mm}$ and the minimum and maximum plant height values were 93 and $110 \mathrm{~cm}$, using applied $\mathrm{N}$ levels. The leaf area varied from 22 to $36 \mathrm{dm}^{2}$ and the heads had average diameter of 86 to $99 \mathrm{~mm}$. With respect to the dry biomass of the heads, there was a variation of 38 to $68 \mathrm{~g}$ and TDB of 68 to $107 \mathrm{~g}$ and W1000 valued between 52 and $65 \mathrm{~g}$ under doses of $\mathrm{N}$. There is considerable variation in all variables mainly due to increased water level in the soil and nitrogen fertilization.
\end{abstract}

Keywords: Helianthus annuus L., irrigation, nitrogen fertilization.

Abbreviations: DAS_days after sowing; N_nitrogen; WRC_water retention capacity; ETo_reference evapotranspiration; AW_available water; $S$ D_stem diameter; $P H_{-}$plant height; LA_leaf area; CD_head diameter; DBC_dry biomass of the head; TDB_total dry biomass; W1000_thousand seed weight; ABA_abscisic acid.

\section{Introduction}

Sunflower is native to North America and currently is grown on every continent, as it has wide adaptability to different environmental conditions and its income is little influenced by latitude, altitude and photoperiod (Zobiole et al., 2010). In Brazil, sunflower is an option preferred as the second crop in the summer (off-season). There are many prospects of cultivation and growth of sunflower in the country. It is mainly due to the production of biofuels and also to serve as a noble edible oil in the market, confectionery, bird foods, silage, meal for animal feed, ornamental production, honey production, and the possibility of export of grain and oil (Person, 2013; Silva et al., 2014). The need to increase production to meet Brazil's domestic demand requires not only the expansion of the agricultural area, but also increase of the crop productivity, depends to several factors such as adequate mineral nutrition of plants and favorable water conditions (Oliveira et al., 2010).

In Brazil, there are problems that limit the productivity of sunflower such as the irregular distribution of rainfall during the year (Silva et al., 2015) and the lack of nutrients in the soils, mainly nitrogen (Faria et al., 2015). The sunflower accumulates large amounts of nutrients, in which the nitrogen $(\mathrm{N})$ is the major one. However, its response to fertilization is limited (Jardini et al., 2014), due to its deep root system which increases the operating capacity and utilization of natural soil fertility and also the fertilizing of the previous crop, with absorption of nutrients from deeper layers (Santos et al., 2013a). Moreover, Santos Jr. et al. (2014) reported that $\mathrm{N}$ is the largest nutritional limiting factor on sunflower productivity and absence of $\mathrm{N}$ provides a reduction of up to $60 \%$ in the potential for sunflower production.

The maximum production of sunflower has been achieved with $\mathrm{N}$ rates between 80 to $90 \mathrm{~kg} \mathrm{ha}^{-1}$. However, with doses of $\mathrm{N}$ between 40 and $50 \mathrm{~kg} \mathrm{ha}^{-1}$ it is possible to obtain $90 \%$ of maximum relative production, which is equivalent to the amount of the nutrient economically efficient (Lobo et al., 2013). Santos et al. (2010) observed that the sunflower exported $71 \%$ of $\mathrm{N}$ of the cumulative total. Santos et al. (2013b) reported that the excess of nitrogen is also harmful, as it causes excessive growth of sunflower, causing sensitive leaves, favorable for the incidence of pests and diseases. In turn, this affects production of grains, as well as problems with lodging and decrease in percentage of oil. Therefore, the amount of $\mathrm{N}$ to be applied needs to be determined for each type of soil, area and crop. The amount of water required for the crop is also not well-defined, but in the majority of the 
cases, 400 to $500 \mathrm{~mm}$ of the water evenly distributed throughout the cycle, result in yields close to the maximum potential (Silva et al., 2014). Despite the sunflower is commonly cultivated as a rained crop, it is not a tolerant plant to drought. However, it can be cultivated in soils with little moisture because usually the root system of this crop reaches the depth around two meters, which increases its water absorption. Dutra et al. (2012) evaluated the growth of sunflower plants in different water retention capacity (WRC) and observed that leaf area, number of leaves, the dry matter of the stem, root and leaf have lower values in $60 \%$ of the WRC. Silva et al. (2012) found that the irrigation equivalent to $50 \%$ of ETo committed the morphology and sunflower biomass production.

The objective of this work was to evaluate the final growth and the biomass of the Helio 253 sunflower hybrid subjected to different levels of nitrogen fertilization and water in the soil.

\section{Results and Discussion}

\section{Analysis of variance}

The results of analysis of variance indicated that there was significant difference at $1 \%$ probability of error for the growth variables and production between treatments with irrigation and also for nitrogen doses. However, there was no interaction between these factors for any of the variables (Table 1).

\section{Stem diameter}

The stem diameter ranged from 13.6 to $19.5 \mathrm{~mm}$ to the level of 50 to $100 \%$ of available water in the soil, respectively (Fig. $1 \mathrm{~A})$, whereas the nitrogen fertilization promoted variation in the diameter of the rod between 14.4 to $18.3 \mathrm{~mm}$ with $\mathrm{N}$ doses equal to 30 and $120 \mathrm{~kg} \mathrm{ha}^{-1}$, respectively (Fig. 1B). These results are confirmed by Leite et al. (2005), which reported that cultivars reached on average from 10 to $80 \mathrm{~mm}$ of stem diameter. According to the authors, the sunflower should get high stem diameter at the end of the cycle to resist lodging and sustain production of heads with many achenes. Biscaro et al. (2008) also reported that increased stem diameter in sunflower are a feature considered desirable to facilitate the implementation of management and cultivation practices. These authors evaluated sunflower plants submitted to $\mathrm{N}$ doses and measured the maximum stem diameter of 18.4 $\mathrm{mm}$, achieved with $\mathrm{N}$ dose equal to $47.8 \mathrm{~kg} \mathrm{ha}^{-1}$. However, the wide range of diameters may be associated with genetic and phenotypic characteristics. Smiderle et al. (2005) observed a significant difference between the stem diameters of different cultivars.

Nezami et al. (2008) reported that the reduction of the stem diameter due to reduced water availability in the soil is mainly due to growth of the main stem and suppression of side branches and; therefore a lower closed partition of dry matter in the stem. Taiz and Zeiger (2009) noted that the growth of the stem is influenced by the same principles that govern the restricted growth of leaves, before the drought.

\section{Plant height}

The plant height in irrigated treatments ranged from $93(50 \%$ AW) to $107 \mathrm{~cm}(100 \% \mathrm{AW})$, with an average of $101 \mathrm{~cm}$ (Fig. 1C). In treatment whose level of water replacement in the soil was $100 \%$ of available water, the plants showed greater height, while the curve adjustment tended to be higher in the treatment with $125 \%$ of the AW. Freitas et al. (2012) also evaluated the sunflower under different levels of irrigation with well-watered and sewage, but observed linear effect of water favorable on plant height, with increments of 17 and $23 \%$ between the minimum and maximum limit of irrigation depth provided for well-watered and sewage, respectively. The lower growth of plants subjected to smaller water depths may be related to the production of abscisic acid (ABA), since this is considered a hormone that retards plant growth and increased in stressed plants by lack of water (Sharp, 2002). The ABA is signaled by the roots and causes a reduction in the rate of transpiration of the plant by stomatal closure, influencing nutrient absorption rate and consequently the physiology and morphology of plants under water stress (Taiz and Zeiger, 2009).

Regarding crop response to different levels of nitrogen fertilization, there was minimum and maximum plant height of $93 \mathrm{~cm}$ and 110 to the levels of 30 and $120 \mathrm{~kg} \mathrm{ha}^{-1} \mathrm{~N}$, respectively (Fig. 1D). This significant effect of nitrogen doses on plant height is consistent with the results obtained by Biscaro et al. (2008) that also observed similar response in sunflower height depending on the doses of N. However, Freitas et al. (2012) and Ribeiro et al. (2015) did not find significant effects of nitrogen fertilization on sunflower growth. Ivanoff et al. (2010), reported that application of $\mathrm{N}$ must be divided and provided as close to the stage of development, when plant needs or can use it. Zagonel and Mundstock (1991) described that the plant height is a reflection of the nutritional conditions during the stem elongation period. It has been verified that the application time was more important to stem elongation than the amount of nitrogen applied.

\section{Leaf area}

The plants with $100 \%$ AW showed leaf area $45 \%$ greater than the treatment with higher water stress and $11 \%$ more than treatment with moisture above the field capacity (125\% AW). There was a quadratic culture with the increase in soil moisture (Fig. 1E). Dutra et al. (2012); however, measured higher leaf area when sunflower plants subjected to flooding, finding linear crop response with a water availability of the soil. Freitas et al. (2012) did not find reduction in the number of leaves with decreasing water availability. They suggested that reduction of leaf area may have been an adaptive defense strategy of the plant to tolerate drought.

Fageria (1989) reported that in drought stress conditions, most vegetables search for alternatives to reduce water consumption, especially reducing transpiration. Within adaptations, the leaf area reduction by decreasing the amount of leaves is widely-known. Taiz and Zeiger (2009) reported that the effects of water stress not only limit the size of individual leaves (cell growth), but also the number of leaves, as they decrease the growth rate of the branches. As the leaf expansion is as low as the production assimilated by photosynthesis, it reflects the production of biomass. The reduction of photosynthesis causes significant growth reduction as few metabolic are produced. Photosynthesis products are essential to nurture and ensure the perpetuation of the species, and not leaving sufficient quantities to be stored, reflected in the low plant growth (Ribeiro et al., 2015). The leaf area as a function of $\mathrm{N}$ doses also showed a quadratic fit, despite not having decrease in the adjustment curve, in which the values ranged from 22 to $36 \mathrm{dm}^{2}$ at doses of 30 and $120 \mathrm{~kg} \mathrm{ha}^{-1} \mathrm{~N}$, respectively (Fig. 1F). Fagundes et al. (2007) also showed that the increase of nitrogen fertilizer 
Table 1. Summary of the analysis of variance for the growth variables at 80 days after sowing (DAS); stem diameter (SD), plant height (PH), leaf area (LA) and head diameter (CD); and variable production to 100 DAS: dry biomass of the head (DBC), the total dry biomass (TDB) and thousand seed weight (W1000) of the sunflower submitted to levels of available water in the soil and nitrogen doses.

\begin{tabular}{|c|c|c|c|c|c|c|c|}
\hline \multirow[b]{2}{*}{ Sources of variation } & \multicolumn{7}{|c|}{ Test F } \\
\hline & $\begin{array}{c}\mathrm{SD} \\
(\mathrm{mm})\end{array}$ & $\begin{array}{c}\mathrm{PH} \\
(\mathrm{cm})\end{array}$ & $\begin{array}{c}\text { LA } \\
\left(\mathrm{dm}^{2}\right)\end{array}$ & $\begin{array}{c}\mathrm{CD} \\
(\mathrm{mm})\end{array}$ & $\begin{array}{c}\text { DBC } \\
(\mathrm{g})\end{array}$ & $\begin{array}{c}\text { TDB } \\
(\mathrm{g})\end{array}$ & $\begin{array}{c}\text { W1000 } \\
\text { (g) }\end{array}$ \\
\hline Blocks & $\mathrm{ns}$ & ns & $\mathrm{ns}$ & ns & ns & ns & ns \\
\hline Available Water (AW) & $* *$ & $* *$ & $* *$ & $* *$ & $* *$ & $* *$ & $* *$ \\
\hline Nitrogen $(\mathrm{N})$ & $* *$ & $* *$ & $* *$ & $* *$ & $* *$ & $* *$ & $* *$ \\
\hline Interaction $(\mathrm{AW} \times \mathrm{N})$ & $\mathrm{ns}$ & ns & ns & $\mathrm{ns}$ & $\mathrm{ns}$ & ns & $\mathrm{ns}$ \\
\hline $\mathrm{CV}(\%)$ & 6.3 & 7.3 & 16.8 & 8.4 & 8.9 & 12.5 & 15.1 \\
\hline
\end{tabular}

$\mathrm{CV}$ - coefficient of variation; ns, $*$ and $* *$ : not significant and significant at 5 and $1 \%$, respectively.
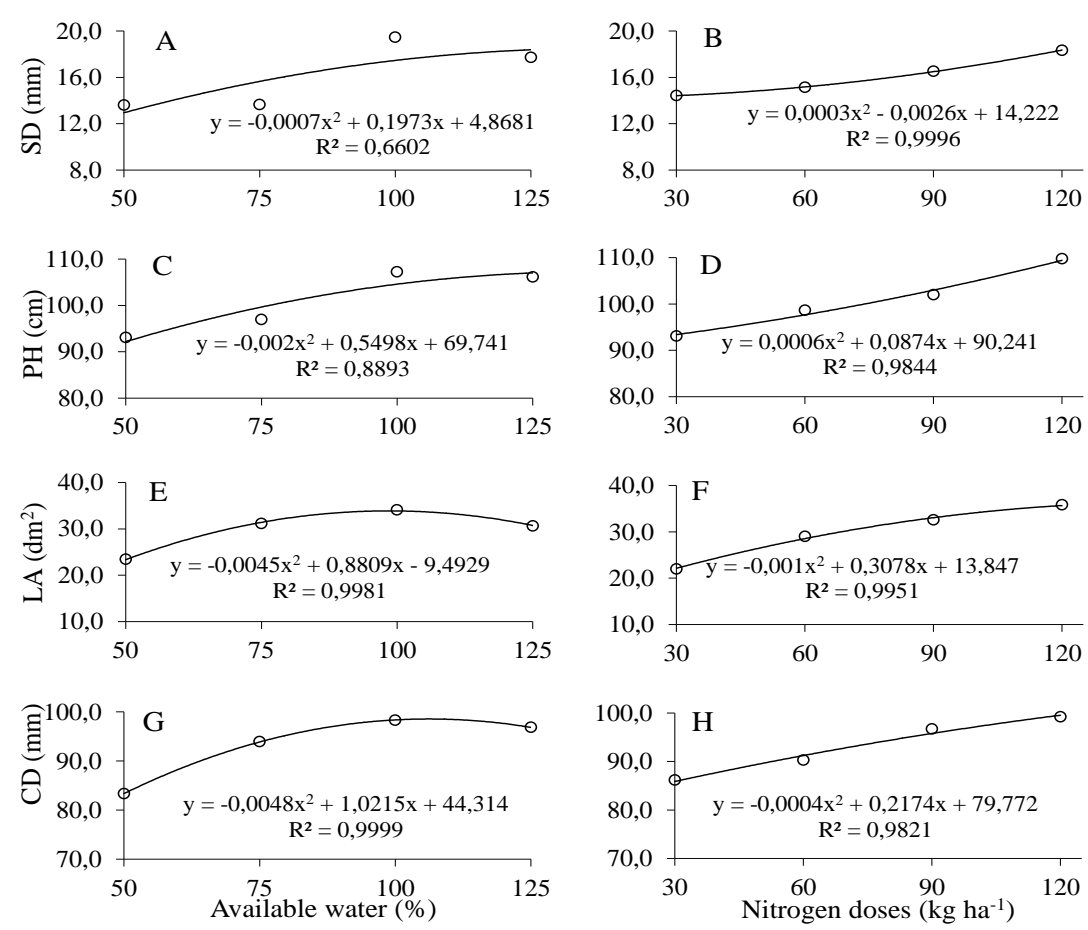

Fig 1. Data of stem diameter (SD), plant height (PH), leaf area (LA) and head diameter (CD) of sunflower at 80 days after sowing (DAS) at levels of available water in the soil and nitrogen doses.
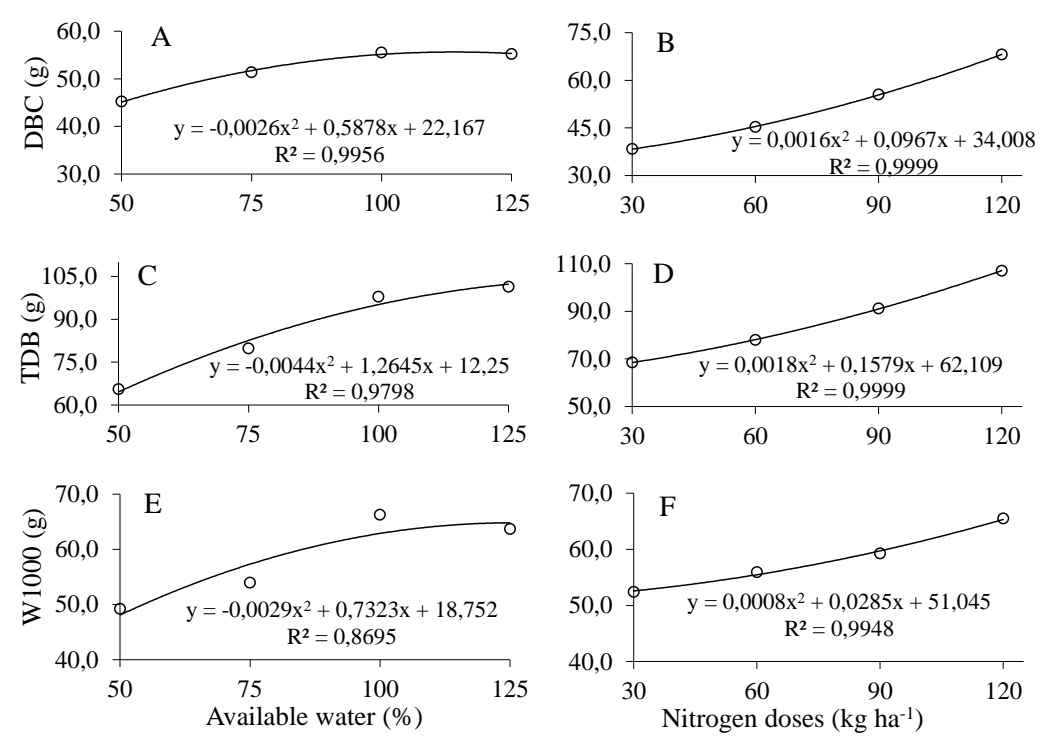

Fig 2. The dry biomass of the head (DBC), the total dry biomass (TDB) and thousand seed weight (W1000) at 100 days after sowing (DAS) in function of levels of available water in the soil and nitrogen doses. 
provides a quadratic increase in sunflower leaf area. As Fernandez et al. (1994), the nitrogen not only affects the rate of expansion, but also cell division, determining the final size of the leaves and it is one of the determining factors of biomass accumulation rate.

\section{Head diameter}

The heads had an average diameter of between 83 and $98 \mathrm{~mm}$ in the treatments of 50 and $100 \%$ of available water, respectively, while the nitrogen afforded variation from 86 to $99 \mathrm{~mm}$ for doses of 30 and $120 \mathrm{~kg} \mathrm{ha}^{-1}$, respectively. These values were lower than those found by Freitas et al. (2012), which measured average diameter of 14.6 and $16 \mathrm{~cm}$ using well-water and sewage, respectively. Biscaro et al. (2008) also observed maximum diameter of the head equal to 11.9 $\mathrm{cm}$ with $44.9 \mathrm{~kg} \mathrm{~N} \mathrm{ha}{ }^{-1}$. Freitas et al. (2012); however, measured the head diameter of $15 \mathrm{~cm}$ with $75 \mathrm{~kg} \mathrm{~N} \mathrm{ha}^{-1}$.

According to Zagonel and Mundstock (1991), the nitrogen acts in the critical stage of flower differentiation, which affects the amount of achenes for each head, and consequently the head diameter. Souza et al. (2010) reported that the head diameter is one of the most sensitive components of production to the presence of nitrogen. However, Biscaro et al. (2008) suggested that the good growth of head diameter does not need a high amount of nitrogen fertilizer, which may warrant finding a maximum point for the dose.

\section{Dry and total biomass of the heads}

The biomass of the heads (Fig. 2A) and total (Fig. 2C), produced by plants to different levels of water replacement, ranged from 45 to $55 \mathrm{~g}$ and from 65 to $101 \mathrm{~g}$, respectively. Regarding the biomass produced according to the nitrogen fertilization, there is the change from 38 to $68 \mathrm{~g}$ (Fig. 2B) and a total of 68 to $107 \mathrm{~g}$ (Fig. 2D) for the lowest and highest dose of $\mathrm{N}$, respectively. The adjustment of regression for biomass formation was increased with increasing $\mathrm{N}$ doses rather than water level, although the coefficient of determination in equation $\left(R^{2}\right)$ have varied between 0.97 and 0.99 , values considered very high as Cargnelutti Filho and Storck (2007).

\section{Weight of thousand seeds per head}

The weight of a thousand seeds per head showed quadratic fit with water levels, with minimum and maximum of 49 and 66 $\mathrm{g}$ for the treatments with 50 and $100 \%$ of available water in the soil, respectively (Fig. 2E). For the nitrogen, there was a higher adjustment regression with values observed between 52 and $65 \mathrm{~g}$ for the $\mathrm{N}$ doses equal to 30 and $120 \mathrm{~kg} \mathrm{ha}^{-1}$, respectively (Fig. 2F). The reduction of total dry biomass and heads to increased water and $\mathrm{N}$ doses can theoretically be a reflection of the values observed especially for leaf area and plant height in response to decreased photosynthesis. It leads to the conclusion that exposure to the tested levels cause low production of achenes and make production in areas with low water availability and $\mathrm{N}$ unfeasible or uneconomical (Andrade and Abreu, 2007; Ribeiro et al., 2015).

Silva et al. (2012) observed that the sunflower biomass is significantly affected when the water deficit occurs in different phenological phases. Therefore, the appropriate water supply in the vegetative phase is essential to promote vigorous growth of the plants and, consequently, high biomass production.

\section{Materials and Methods}

\section{Characterizationof area}

The experiment was conducted from March 10 to June 10, 2012 in a greenhouse, in the Academic Unit of Agricultural Engineering (UAEAg) of the Federal University of Campina Grande (UFCG) in Campina Grande- PB. The region climate, according to Köppen climate classification, is the type Csa, mesothermal, sub humid, with periods hot and dry (4 to 5 months) and rainy from autumn to winter. The average annual precipitation in the region is $804 \mathrm{~mm}$ (Macedo et al., 2011).

\section{Treatments}

The design was split-plots in completely randomized with the treatments consisted of four levels of moisture in the soil (50, 75,100 and $125 \%$ of available water) and four nitrogen doses $\left(30,60,90\right.$ and $\left.120 \mathrm{~kg} \mathrm{ha}^{-1}\right)$. Each experimental unit consisted of a plastic vase with volumetric capacity of $30 \mathrm{~L}$, with $20 \mathrm{~kg}$ of soil to grow a sunflower plant until 100 days after sowing. The soil used (Entisol Eutrophic of sandy loam texture) was collected in São José da Mata -PB in the surface layer $0-20 \mathrm{~cm}$.

\section{Plants materials}

The cultivar studied was the hybrid Helio 253, which stands out for precocity (average growing cycle of 100 days). The sowing was done manually by placing seven seeds per hole. The thinning was performed 10 days after sowing (DAS) leaving three plants per pot, and 20 DAS is only one plant per pot. The soil was fertilized as recommended by Novais et al. (1991). The nitrogen was applied to cover in the form of urea, $40 \%$ at planting, $40 \%$ to 20 DAS and the rest at 30 DAS. The daily handling of irrigation was performed with the aid of sprinklers and graduated cylinder, wherein the water requirements of the culture were determined by the water balance in the soil by weighing vessels method. Before planting, the soil was irrigated bringing the water content to field capacity to promote seed germination.

\section{Traits measured}

The growth variables (stem diameter, leaf area, plant height and head diameter) were measured at 80 DAS. At 100 DAS, the production variables (total dry biomass, heads and thousand seeds weight) were obtained. The plant height was measured from the plant neck to the base of the youngest leaf and the stem diameter measurement was performed with a caliper, with the readings being made in the cervical region of each plant. The measurement of the sunflower head diameter was held with the aid of a graduated ruler at harvest. The calculation of the leaf area (LA) calculated according to Maldaner et al. (2009), whose formula is $\mathrm{AF}=0.1328 \times$ $\mathrm{C}^{2,5569}$, wherein ' $\mathrm{C}$ ' is the length of the leaf midrib, and the total sum of the areas per leaves provides the value of the total leaf area of the plant. The dry biomass was obtained after drying the material circulating air oven at $60{ }^{\circ} \mathrm{C}$ until constant weight and then weighed on precision balance.

\section{Statistical analysis}

The growth variables and yield per plant were subjected to analysis of variance by test $\mathrm{F}(\mathrm{p} \leq 0.05)$ and when significant, 
the regression studies to water levels and nitrogen fertilization were performed.

\section{Conclusion}

The nitrogen fertilization and available water in the soil increased all growth variables and sunflower biomass. With the increasing levels of treatments the growth variables enhanced. The smaller performances were obtained in the treatments with $50 \%$ of available water and $30 \mathrm{~kg} \mathrm{ha}^{-1} \mathrm{~N}$, while the best performances were obtained at $100 \%$ of available water and $120 \mathrm{~kg} \mathrm{ha}^{-1} \mathrm{~N}$. However, there was no interaction between these factors according to the statistical analysis.

\section{Acknowledgement}

We thank CAPES and CNPq for their contribution to the research

\section{References}

Andrade JA, Abreu FG (2007) Influência da temperatura e do teor de umidade do solo na área foliar e acumulação de matéria seca durante o estabelecimento da ervilha, do milho e do girassol. Rev de Ciên Agrár. 30:27-37.

Biscaro GA, Machado JR, Tosta MS, Mendonça V, Soratto RP, Carvalho LA (2008) Adubação nitrogenada em cobertura no girassol irrigado nas condições de Cassilândia-MS. Ciên e Agrotec. 32:1366-1373.

Cargnelutti FILHO A, Storck L (2007) Estatísticas de avaliação da precisão experimental em ensaios de cultivares de milho. Pesq Agropec Bras. 42:17-24.

Dutra CC, Prado EAF, Paim LR, Scalon SPQ (2012) Desenvolvimento de plantas de girassol sob diferentes condições de fornecimento de água. Semina: Ciên Agrár. 33:2657-2668.

Fageria NK (1989) Solos tropicais e aspectos fisiológicos das culturas. In: Embrapa/DPU, 1edn , Brasília, p 425.

Fagundes JD, Santiago G, Mello AM, Bellé RA, Streck NA (2007) Crescimento, desenvolvimento e retardamento da senescência foliar em girassol de vaso (Helianthus annuus L.): fontes e doses de nitrogênio. Ciên Rur. 37:987993.

Faria AJG, Freitas GA, Georgetti ACP, Ferreira JJM, Silva MCA, Silva RR (2015) Efeitos da adubação nitrogenada e potássica na produtividade do capim mombaça cultivados sobre adubação fosfatada. J Bioen and Food Sci. 2:98-106.

Fernandéz S, Vidal D, Simom E, Sol13-Sugrantes L (1994) Radiometric characteristics of Triticumaestivum cv. Astral under water and nitrogen stress. Intern $\mathrm{J}$ Remote Sens. 15:1867-1884.

Freitas CAS, Silva ARA, Bezerra FML, Andrade RR, Mota FSB, Aquno BF (2012) Crescimento da cultura do girassol irrigado com diferentes tipos de água e adubação nitrogenada. Rev Bras de Eng Agríc e Amb. 16:1031-1039.

Ivanoff MEA, Uchôa SCP, Alves JMA, Smiderle OJ, Sediyama T (2010) Formas de aplicação de nitrogênio em três cultivares de girassol na savana de Roraima. Rev Ciên Agron. 41:319-325.

Jardini DC, Scaramuzza WLMP, Weber OLS, Borba FAB, Fernandes DÁ (2014) Absorção de nutrientes em genótipos de girassol. Pesq Agrop Trop. 44:434-442.

Leite RMVBC, Brighenti AM, Castro C (2005) Girassol no Brasil. In: Embrapa Soja, p 613.
Lobo TF, Grassi FH, Bull LT, Kummer ACB (2013) Efeito do lodo de esgoto e do nitrogênio nos fatores produtivos do girassol. Rev Bras de Eng Agríc e Amb. 17:504-509.

Macedo MJH, Guedes RVS, Sousa FAZ (2011) Monitoramento e intensidade das secas e chuvas na cidade de Campina Grande/PB. Rev Bras de Climat. 8:105-117.

Maldaner IC, Heldwein AB, Loose LH, Lucas DDP, Guse FI, Bortoluzzi MP (2009) Modelos de determinação não destrutiva da área foliar em girassol. Ciên Rur. 39:13561361.

Nezami A, Khazaei HR, Boroumand RZ, Hosseini A (2008) Effects of drought stress and defoliation on sunflower (Helianthus annuus) in controlled conditions. Desert. 1:99104.

Novais RF, Neves JCL, Barros NF (1991) Ensaio em ambiente controlado: Métodos de pesquisa em fertilidade do solo. In: Embrapa-SEA, Brasília. p 189-253.

Oliveira FA, Oliveira FRA, Campos MS, Oliveira MKT, Medeiros JF, Silva OMP (2010) Interação entre salinidade e fontes de nitrogênio no desenvolvimento inicial da cultura do girassol. Rev Bras de Ciên Agrárs. 5:479-484.

Person LC (2013) Ótima opção para o agronegócio brasileiro. Agroanalysis. 33:27-28.

Ribeiro PHP, Silva S, NETO JD, Oliveira CS, Chaves LHG (2015) Crescimento e componentes de produção do girassol em função da irrigação com água salina e adubação nitrogenada. Eng na agric. 23:48-56.

Santos JF, Grangeiro JIT, Wanderley JAC (2013a) Comportamento produtivo do girassol em função de doses de nitrogênio. Rev Verde de Agroec e Desenv Sustent. 8:291-296.

Santos JF, Wanderley JAC, Sousa JJR (2013b) Produção de girassol submetido à adubação organomineral. Agropec Cient no Semi-Árido. 9:38-44.

Santos JJA, Gheyi HR, Dias NS, Araujo DL, Guedes Filho DH (2014) Substratos e diferentes concentrações da solução nutritiva preparada em água residuária no crescimento do girassol. Rev Ciên Agron. 45:696-707.

Santos LG, Souza UO, Primo DC, Silva PCC, Santos AR (2010) Estado nutricional da cultura do girassol submetida à adubação com fósforo e boro. Enciclop Biosf. 6:1-14.

Sharp RE (2002) Interaction with ethylene: changing views on the role of abscisic acid in root and shoot growth responses to water stress. Plant Cell Environ. 25:211-222.

Silva ARA, Bezerra FML, Freitas CAS, Pereira Filho JV, Andrade RR, Feitosa DRC (2012) Morfologia e fitomassa do girassol cultivado com déficits hídricos em diferentes estádios de desenvolvimento. Rev Bras de Eng Agríc e Amb. 16:959-968.

Silva C, Silva RA, Vale WG, Mello ACT (2014) Reação de cultivares de girassol (Helianthus annuus L.) a Meloidogyne incognita raça 3 e Meloidogyne javanica. Glob Sci Techn. 7:7-15.

Silva S, Dantas Neto J, Teodoro I, Souza JL, Lyra GB, Santos MAL (2015) Demanda hídrica da cana-de-açúcar irrigada por gotejamento nos tabuleiros costeiros de Alagoas. Rev Bras de Eng Agríc e Amb. 19:849-856.

Smiderle OJ, Mourão Júnior M, Gianluppi D (2005) Avaliação de cultivares de girassol em savana de Roraima. Rev Acta Amaz. 35:331-36.

Souza RM, Nobre RG, Gheyi HR, Dias NS, Soares FAL (2010) Utilização de água residuária e de adubação orgânica no cultivo do girassol. Rev Caat. 23:125-133.

Taiz L, Zeiger E (2009) Fisiologia vegetal. In: Armed, 4edn, Porto Alegre, $\mathrm{p} 848$. 
Zagonel J, Mundstock CM (1991) Doses e épocas de aplicação de nitrogênio em cobertura em duas cultivares de girassol. Pesq Agropec Bras. 26:1487-1492.
Zobiole LHS, Castro C, Oliveira FA, Oliveira Júnior A (2010) Marcha de absorção de macronutrientes na cultura do girassol. Rev Bras de Ciên do Solo. 34:425-433. 